\title{
Cooking gas (LPG) Distribution to Rivers State Homes, Case Study: Choba Community
}

\author{
Azubuike H. Amadi, Gogo-Isaiah E. Uneh, Onaivi C. Ene, Franklin C. Onwa, and Djoï N. André
}

\begin{abstract}
Liquefied Petroleum Gas has proved to be an essential source of fuel through the mild blue glowing flame it produces on ignition in the presence of oxygen. This source of heat has made it suitable for use as cooking gas. Various developed countries have been able to transport gas to homes for heating of homes and as cooking gas using grids while considering environmental conditions specific to that country. This study unveils a distribution mechanism for effectively transporting cooking gas safely to homes in Rivers State. This gas distribution plan is a one supplier strategy which could be government or private owned. Choba community was used as a choice case study because of its strategic position. Also, the gas properties such as RVP, Pressure and Temperature were analyzed together with the pipe properties. The project impacts on the major environmental components of the study area were assessed and considered. The distribution routes considered locations of present gas processing plants in Rivers State and optimized routes for transport was introduced. Local terminals to ease distribution, monitoring and safety were also included. The economic analysis of this study will show how the distribution of cooking gas to homes can increase the utilization of Nigerian gas and improve the benefits from Nigerian gas in the next 10 years.
\end{abstract}

Index Terms - Cooking gas, LPG, Natural Gas, Gas distribution, Gas revolution, RVP, Gas transportation terminals, Gas metering, safety, NPV, PI.

\section{INTRODUCTION}

With a population of about 203 million people, Nigeria is the country with the most population within the OPEC. Nigeria is located on the Gulf of Guinea, Africa's western coast. The proven Natural gas reserves is about 5.675 trillion cubic meters of which it currently exports 28.6256 million cubic meters [17]. Liquefied Petroleum Gas (LPG) is the major gas distributed as cooking gas, mostly at low pressure composing majorly of $\mathrm{C}_{3} \mathrm{H}_{8}$ and $\mathrm{C}_{4} \mathrm{H}_{10}$. Several companies such as Shell, Total, BP, Agip, etc. have been involved in the production of these gases for decades. Therefore, the large reserve of natural gas makes the gas business a profitable course.

Laterally, attention is drawn to the related environmental issues. The Sustainable Development Goals (SDGs) include ensuring universal access to affordable, reliable, and modern energy services by 2030 with its accessibility through a network or supply chain [24]. Globally, more than 2.8 billion

Submitted on April 27, 2021

Published on June 11, 2021

A. H. Amadi, the World Bank Africa Centre of Excellence in Oilfield Chemicals Research, University of Portharcourt, Nigeria.

(e-mail: azubuikehopeamadi@gmail.com)

G. E. Uneh, Greenville LNG Limited, Nigeria.

(e-mail: unehisaiah@gmail.com) people use solid fuels like firewood and charcoal for cooking and heating [25]. Exposure to the resulting air pollution is one of the world's greatest environmental health risks, estimated to lead to 3.8 million annual premature deaths in 2012 [12]. Government, civil societies, and developers have become upright on ensuring that sustainable practices critical to reduction of related environmental concerns through LPG development are adopted.

Methane is known to be a colorless and odorless gas so as other gases contained in the LPG mixture. Therefore, LPG is mixed with mercaptans during processing. Mercaptans are organic sulfur compounds having a general formula R-S-H, chemical formula $\mathrm{CH}_{4} \mathrm{~S}$ and density of $0.9 \mathrm{~g} / \mathrm{ml}\left(\right.$ at $0{ }^{\circ} \mathrm{C}$ ). They occur in fractions but cannot be removed by mere distillation. They are responsible for the bad smell and corrosive properties during pipeline transmission. However, their effect can be reduced in the sweetening plant in processes such as Merox process [21].

According to the world LP Gas Association LP gas is a vital source of energy for tens of millions of people around the world. These gases are transported through pressurized cylinders or transmitted through pipelines, but for the purpose of this study, we will be discussing on transmission directly to homes for cooking through a source which will be regulated and metered. The scope will be narrowed down to Choba community in Rivers State, Nigeria because of its strategic location of being around the center of the state as shown in Fig. 1.

In Rivers State, we have the Obiafu-Obrikom (OB-OB) gathering station owned by NAOC, which links Kwale gas plant in Delta State and Akri plant in Imo State [15]. Also, the NAOC pipeline carries NGL and Fuel gas to Indorama Petrochemical Company at Eleme from the Brass Terminal.

At Rumuji, the main manifold of Greenville is located, linking gas supply from AGIP, Total and SPDC gas plants [9], while Shell's Portharcourt cluster in Rivers State aims at distributing gas to industries around the greater Portharcourt [20].

According to NAPIMS (National Petroleum Investment Management Services) Obiafu Obrikom plant has a capacity of 2,070 Mscf/d (gas) and occupies 23 host communities and 6 transit communities [13], while Greenville has a gathering capacity of about 2250tons of LNG [8].

O. C. Ene, The Emerald Energy Institute, University of Portharcourt, Nigeria.

(e-mail: ceneonaivi@gmail.com)

F. C. Onwa, National Open University of Nigeria, Nigeria. (email: onwafranklin@gmail.com)

D. N. André, The World Bank Africa Centre of Excellence in Oilfield Chemicals Research, University of Portharcourt, Nigeria.

(e-mail: djoi.andrew@gmail.com) 


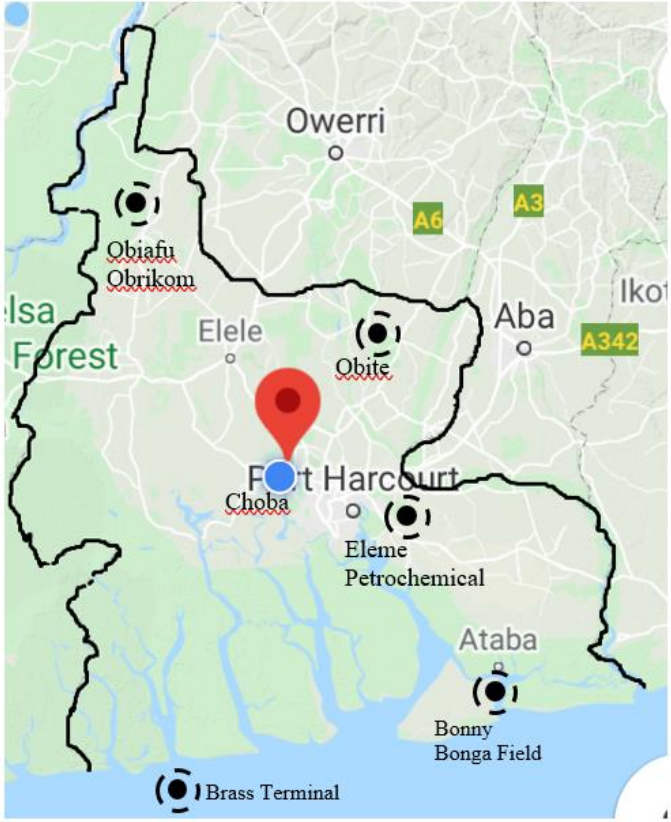

Fig. 1. Key areas of gas production and gathering.

\section{A. Network Code}

Nigeria has large gas proven reserves of over 200tcf and can get up to 600 tcf if it is properly explored, recording as $1^{\text {st }}$ in Africa and $9^{\text {th }}$ in the world. Just as the population of the country keeps increasing, so is the energy demand. Pipeline transport network code has also been a challenge with less than $10 \mathrm{miles} / \mathrm{tcf}$ and producing about $8 \mathrm{bscf} / \mathrm{d}$ with approximately $10 \%$ flare which is gradually been improved on by recent installations. Nigeria is presently looking towards copying the network code used in UK although our system is seen as a point-to-point system and not a network grid. With improvement in the pipeline distribution network, Nigeria is forecasted to arrive at an efficient network system in few years' time. The efficiency of the network code system comes with lots of merits such as a contract system where all stakeholders are open to the same contract, effective shrinkage calculations and metering, Capacity transfer, integrity assessment, supervisory control, and data acquisition, etc. as shown in Fig. 2. However, challenges such as balancing systems are essential. A monthly balancing was suggested for Nigeria due to its less complex network. IT is also an issue posed on pipeline network. Lots of software's will be needed for monitoring meter and volumetric flow, gas chromatographs, hydrogen, and moisture dew point across pipeline networks [28].

- Network Code Regime

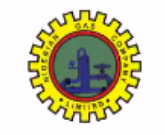

Gas Transporter

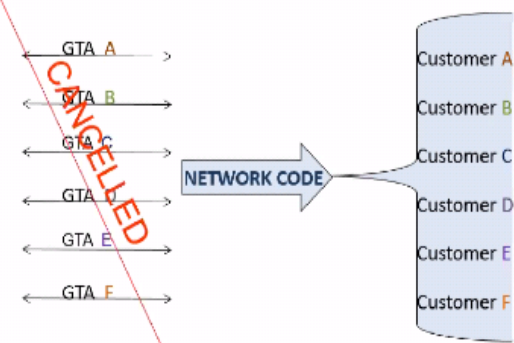

Fig. 2. Pictorial representation of Network Code minimizing complexity of contracts between transporters and customers [28].
RVP (Reid Vapor Pressure): This is the measurement of the volatility of petroleum and gas products. This is essential in transportation since it defines the absolute vapor pressure exerted by the gases at $100{ }^{\circ} \mathrm{F}\left(37.8^{\circ} \mathrm{C}\right)$ using ASTM-D-323 method of measurement as shown in Fig. 3. It is used as a reference vapor pressure to the present vapor pressure of the gas, with respect to the vapor pressure which it will be during transportation to avoid much escape of light ends.
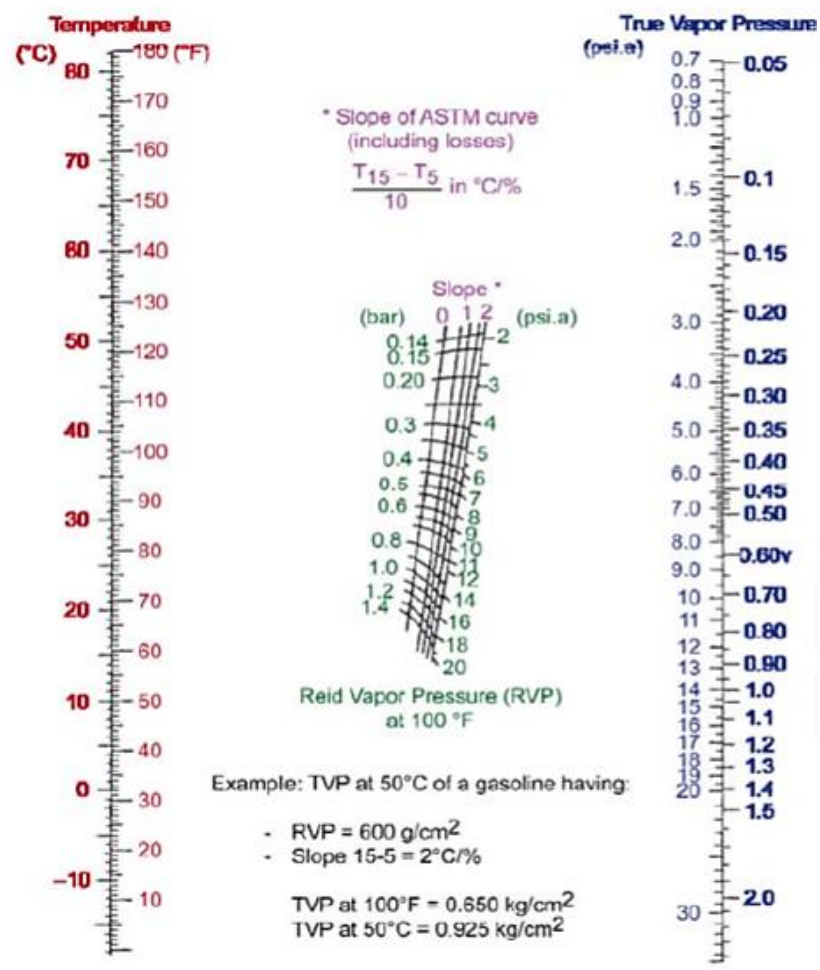

Fig. 3. Typical chat for RVP and TVP comparison, showing how temperature affects the vapor pressure [19].

\section{AIM AND OBJECTIVES}

\section{A. Aim}

The aim of this study is to design a cooking gas distribution plan for Rivers State.

\section{B. Objectives}

1) To safely deliver gas to homes in Rivers State.

2) To analyze the cost of delivery, using upscale technologies.

3) To improve regulation of gas and monitoring of gas usage in the state.

4) To ensure the environmentally sustainable of gas delivery.

5) To effectively utilize Nigerian Gas.

\section{LITERATURE REVIEW}

In June 2019, SPDC made a press release, identifying that its gas distribution in Nigeria has increased to over $150 \%$ after completion of its Gas Train in Agbara-Ota [2], While NLNG, with its Train 7 plans to further improve gas production and distribution capacity. This shows that the demand is increasing and its necessary to improve home delivery for efficient utilization.

Igwe et. al. noted that the lack of effective transmission and utilization of Nigerian gas is the major cause of gas flaring in 
the country. In $1983,78.65 \%$ of the total gas produced was flared, reaching approximately $106.36 \mathrm{~T}$ kcal/year (1.241 GSCF/D). This study, however, opens more opportunities for gas utilization and distribution around the country, which will eventually reduce flaring [10].

In Chikwe et. al. study of Nigerian Premium Motor Spirit (PMS), RVP was 0.5 compared to ASTM maximum RVP of 0.6. this show that gas will be higher $(>0.6)$ while heavier ends will be lower. His work also showed that adulterated PMS products have lower RVP, which possess challenges in use [4]. Faruq et. al. also compares the RVP of Nigerian Gasoline to Brazil, Holland, Kuwait, and Russia, arriving at $0.48,0.5,0.44,0.56,0.55$, respectively [6].

The United State, with about 3 million miles of pipeline network, have been able to successfully distribute gas to across the country. About 28 trillion cubic feet of natural gas was distributed to about 75 million customers in 2018 making use of gathering systems with low pressure pipelines (small diameter) and high pressure pipelines for interstate transmission. The high demand and prices made producers within 2003 to 2008 to expand development of existing field and exploration of underdeveloped gas fields [5].

Smart Energy International is presently improving on smart gas metering which has greater advantages of real time monitoring, billing accuracy and improved customer service ahead of conventional gas and electric metering systems [16].

Presently, the Nigerian government in a bid to improve gas utilization in the country has flagged off the Ajokuta-KadunaKano Gas Pipeline project which is and interstate project of about $614 \mathrm{~km}$ linking the $1300 \mathrm{~km}$ Trans-Nigeria Gas pipeline at a worth of $\$ 2.59 \mathrm{bn}$. The thickness of the pipeline project is 40 inch showing a large transport of gas to boost gas utilization at an estimated pressure of 1000 psig [3].

\section{Methodology}

The area of consideration was mapped out and the major routes for transportation were identified to be along the Federal roads and the State roads considering the blueprint mapped out for the Rivers State as shown in Fig. 5. Fig. 4 shows typical gas delivery system mechanism to homes.

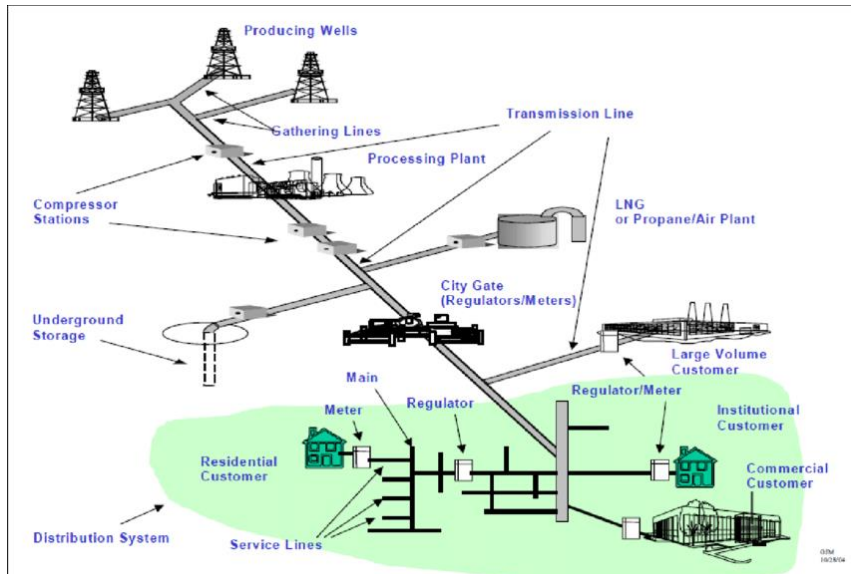

Fig. 4. Gas delivery system from producing wells to homes [23].
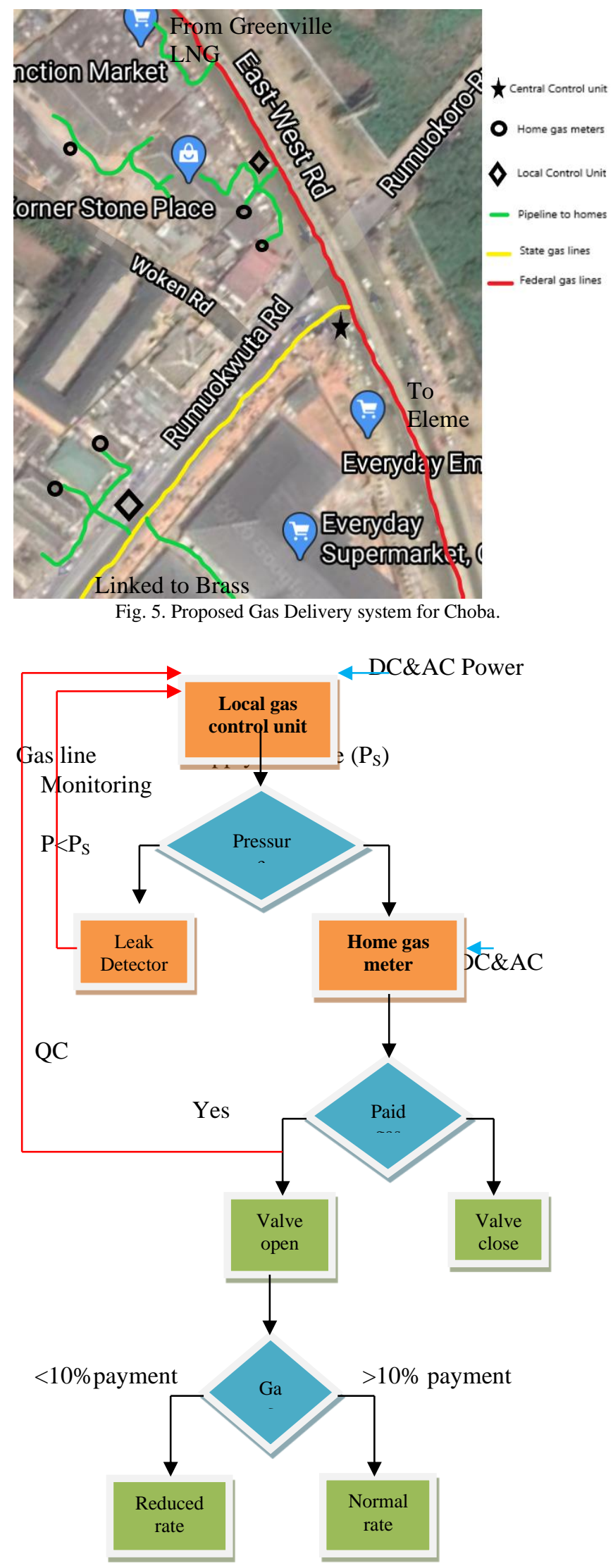

Fig. 6. Flow Chart of Gas Metering \& Monitoring System.

\section{A. Determination of Supply Pressure}

The pressure difference in relation to the temperature for this project is assumed not significant because the supply of cooking gas from the production site to the control units and down to homes are in same region with relatively the same temperature. Therefore, the RVP will not be relevant in 
distribution calculations, however, if the networks are expanded to interstate or between countries, RVP gets relevant. The gantry for delivery will be designed at 22 bar.g and pressure supply across Choba will be estimated below 22 bar.

\section{B. Design and Durability}

For an effective distribution that will stand the test of time, the following conditions should be taken into consideration:

1. Design life of the distribution unit and associated facilities must not be less than 30 years, with 5-year routine maintenance intervals.

2. Cathodic protection of pipelines at specific points, while considering the area pipe is laid.

3. Welding considerations are also important. Weldments should be defect free while heat affected zones should match the toughness and mechanical properties of the line pipe.

4. Plastic materials such as PE, PVC, and ABS if used in the flowline should be tested for aging effect, which hydrogen could cause.

5. Test meters should be calibrated to avoid losses during distribution.

6. Fatigue of line pipes and other materials used must be pressure-tested and ascertained to be well fit for the endurance limits it will face during service.

7. There is a tendency of gas to leak through valves, seals, pipes, gaskets, etc. therefore the pressure reduction monitoring device should not be the only safety measure. However, all joints should be carefully fastened with airtight materials, and tested before putting in service.

8. Materials for transport of gas should be tested for compatibility with the cooking gas.

9. Repair procedures of pipeline while in service should be put in place, in line with best practices.

10. Limit the presence of oxygen in gas line to avoid creating an explosive environment [13].

11. Ensure distribution lines are well buried or surfacelaid in the highest safety considerations, and caution signs adequately marked.

\section{Distribution Route}

Care should be taken during selection of the $15 \mathrm{~km}$ distribution route to ensure the following are achieved:

1. Homogenous soil conditions, as easy to remove as possible, and little interference with landowners.

2. Avoidance of environmentally sensitive areas susceptible to violence, erosion, and flooding.

3. Minimization of crowded routes and crossing points such as roads, water, and existing structures.

4. Sufficient accessibility to the distribution line.

\section{Materials for Cooking Gas Distribution}

The work is a cooking gas project which entails a Liquefied Petroleum Gas (LPG) reception and distribution station. This station is expected to have an initial storage capacity of $7,000 \mathrm{~m}^{3}$ of combined Propane, Butane and LPG (Propane + Butane).

LPG in Nigeria, which is usually a mixture of Propane (30\%) and Butane $(70 \%)$ is done in such proportions to achieve optimum safety and a good heating value from the fuel. As a product from processed raw natural gas, the target source as feed to our proposed facility siting is a gas processing plant (Greenville, Rumuji) which is about $15 \mathrm{~km}$ away from Choba. It is agreed that the cooking gas will be piped and delivered to the reception station by a booster pump over the distance, which is expected to be greater than the facility reception pressure and will be stepped down before storage.

\section{1) Inlet Facility}

At the inlet, the first device will be an Emergency Shut Down Valve (ESDV) with an equalization bypass line for pressurization of the inlets during product feeds due to the excessive pressure supplied from the booster pump. This helps to gradually pressure the facility and normalizes the pipeline before entering the storage and later for distribution.

\section{2) Instrument Air Emergency Shutdown Unit}

This unit will serve as the storage for Instrument Air which will be produced or generated by an Instrument Air Compressor and piped to a drum for storage. This will make air readily available for valve actuations in case of emergencies.

\section{3) Metering Unit/Skid}

This unit serves the responsibility of measuring or accounting for the volume of gas received at the facility. These records and measurements are carried out with a flow meter. Fig. 6 shows a flow chart of a proposed metering and monitoring system for the local control units. This proposition can be used for bill payments through the meters that will be installed at the homes of the consumers at Choba. A typical design of those meters was also shown in Fig. 9 \& 10. The design was to make the process seamless and automated.

\section{4) Gas Pressure Reduction Station}

It is expected that the booster pump will deliver the product (LPG) across a distance of about $15 \mathrm{~km}$ which means a highpressure product should be expected at the inlet and will be stepped down at the GPRS to about 3 - 5 bar at the tank farm for storage. This reduction in pressure is done by Pressure Control Valves (PCVs).

\section{5) Tank Farm}

This is where the LPG will be stored. It will consist of 20 LPG storage tanks each with a storage capacity of $350 \mathrm{~m}^{3}$, design pressure of 20 bar.g and design temperature of $29 / 500{ }^{\circ} \mathrm{C}$. The tanks will be installed horizontally to minimize boil-offs as shown in Fig. 7 and excess column of gas which could increase the internal pressure of the vessel. It is to have:

$$
\begin{aligned}
& \text { Length }=28,000 \mathrm{~mm} \\
& \text { Diameter }=3,800 \mathrm{~mm} ; \\
& \text { Capacity }=350 \mathrm{~m}^{3} .
\end{aligned}
$$

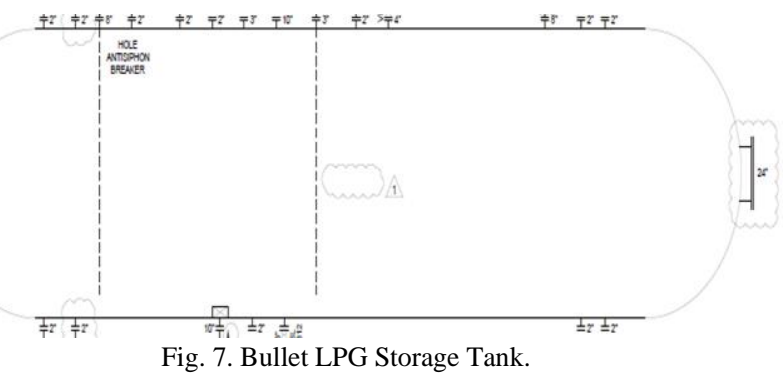


Total tank farm storage capacity $=7,000 \mathrm{~m}^{3}$. With room for extra storage tanks in case need arises for expansion.

2 Load out Pumps (One on standby) could be adopted for distribution from the storage tank to control points at Choba. An example of the pump for distribution is the centrifugal pump shown in Fig. 8. However, smaller pumps could be used along the lines to home at from local control points.

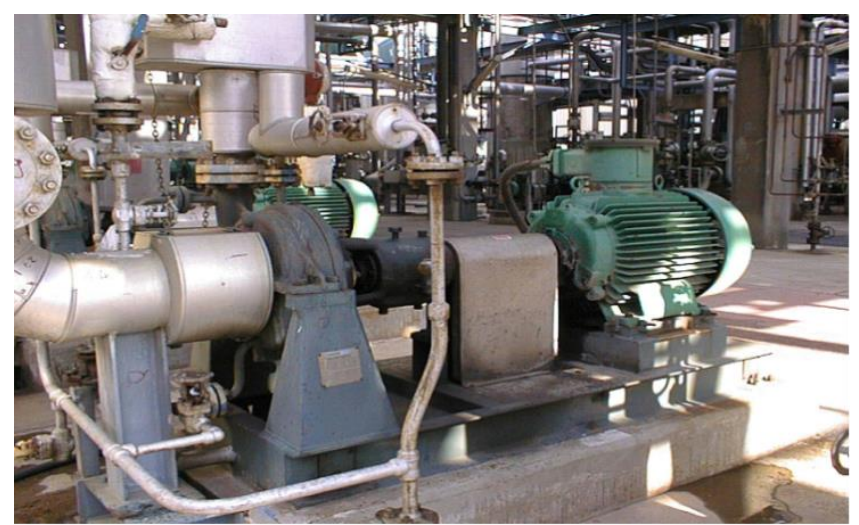

Fig. 8. Centrifugal Pump.

\section{6) Gantry}

This will serve as a service point for vehicular refueling and trucking purposes. It is expected to have a weighbridge and connected directly to the tank farm and load out pumps. For safety purpose, standby pumps (hydrant layout or water pipes) must be mounted around the loading area. Safety officer's / fire fighters must be prepared for any eventuality. The gantry should have at least 4 arms during the early stage of startup and space for expansion. The design should consider:

Design pressure $=22 \mathrm{bar} . \mathrm{g}$;

Design Temperature $=-49 / 500{ }^{\circ} \mathrm{C}$.

\section{7) Central Control Room}

The room from where the whole control and monitoring will be carried out using a panel, by sending signals to activate or actuate equipment and instruments. This is done by the aid of cables, and instrumentation of the whole facility.

\section{8) Fire and Alarm Systems}

Generally, consists of gas detectors, smoke detectors, fire extinguishers, deluge water system etc. This will be needed in the event of gas leaks and explosions.

\section{9) Others}

Nitrogen Compressor (To produce or generate low purity Nitrogen for vessel purging and maintenance), $16 \mathrm{~km}$ 6inch pipe (extra $1 \mathrm{~km}$ to serve as safety factor), fittings, flanges, connectors, manual valves, ESDs, Pressure gauges, transmitters, $3 / 4$ " pipes, sight glasses etc.

\section{0) Environmental Data}

Public consultations, questionnaires, field observation, checklists, and extensive literature review were the main sources of primary data for the study. Risk analysis and Environmental Impact Assessment were also performed for the different phases from construction to distribution, to identify the potential impacts on environmental components of the study area. The population consists of all residents in Choba town estimated at about 24105 using 3.5\% annual growth rate [26].

\section{RESULTS AND FINDINGS}

To ensure customer satisfaction and seamlessness of the proposed LPG distribution plan for Choba community, a proposed design (shown in Fig. $9 \& 10$ ) for the metering system to be install at the end consumer points was developed. It will be adapted to the deign structure shown in Fig. 6 for monitoring of leaks at the control units, for bill payments at the consumer end, and for gas supply \& flow capacity at every point in time. This will be a useful equipment for both the operators and the consumers. For safety and security purposes, it will be encrypted to avoid hacking and maintain accuracy in supply and payments to contractor and or government.

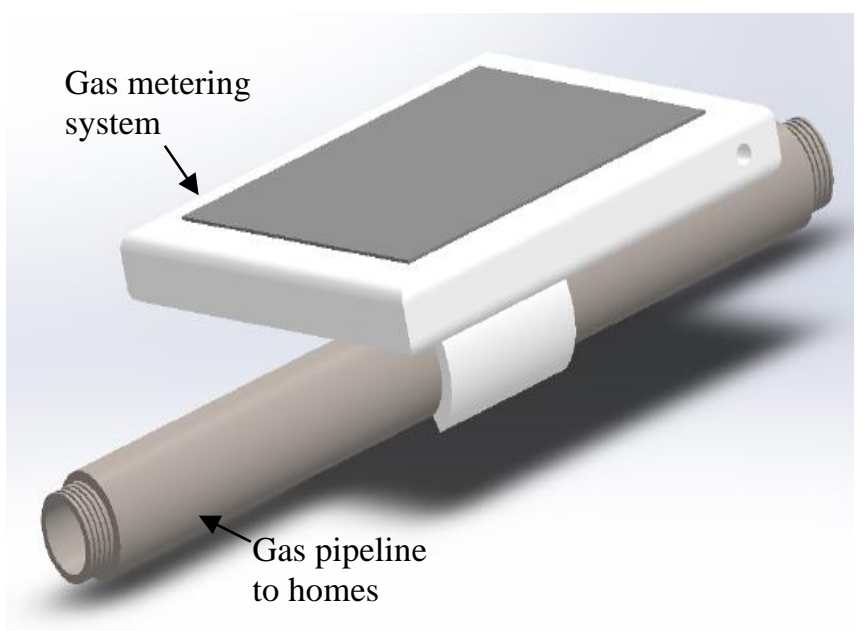

Fig. 9. Gas Meter for Homes.

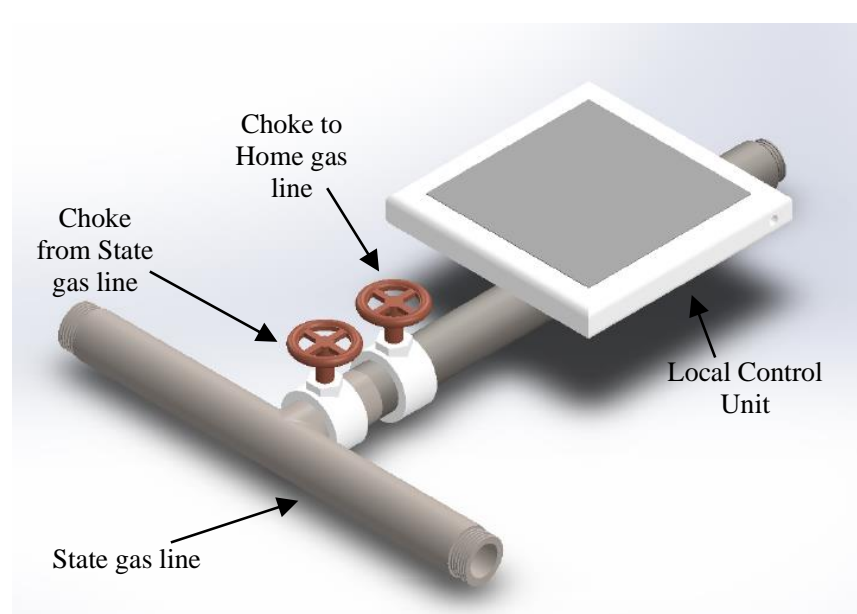

Fig. 10. Local control unit at junction between federal/state line and home lines.

\section{A. Economic Analysis}

Making the decision to invest in the oil and gas industry is always a difficult task. Many high risk factors associated with the petroleum industry, such as long term investment horizons, relatively high initial investment requirements, and negative cash flow during the first few years, have an impact on these projects [11]. These factors, combined with dangerously volatile price levels, raise the number of uncertainties in the data used to make investment decisions in petroleum projects to a dangerously high level.

The demand for LPG consumption in Nigeria is estimated at about 600,000 metric tons per year and the spike in growth 
is due to the swift conversion of many domestic and commercial users to cooking gas, as it is seen as a clean source of fuel. An approximate market price for camp cylinder bottles of $3 \mathrm{~kg}$ was about $5000,6 \mathrm{~kg}$ and $12 \mathrm{~kg}$ were $\$ 8000$ and $\$ 12000$, respectively. Most of these camp cylinder bottles are imported, putting more cost on a gas producing country like Nigeria [22].

One of the objectives of this paper is to figure out whether or not distributing LPG to households in Choba by LPG cylinder (called Cylinder-Option in this paper) is more profitable than by pipeline (Pipeline-Option). The economic analysis consists of evaluation the profitability of each option and show which one of both options is more viable. The economic evaluation model used is an existing method in the literature. NA hypothetical case study is used. Some information (data) is collected from people owning gas filling plants in Choba region and the remainder from the literature. The economic indexes to be used indeed are the Net Present Values (NPV) and the Profitability Indexes (PI) of the projects (options). The net present value (NPV) is defined as the difference between the sum of the discounted cash flows expected from the investment and the amount initially invested [7]. It is calculated as follow:

$$
N P V=\sum_{t=0}^{N} \frac{C F_{t}}{(1+D)^{t}}
$$

with: $\mathrm{CF}_{\mathrm{t}}=$ the Cash Flow at the end of the year $\mathrm{t}$; $\mathrm{D}=$ discount rate, $\mathrm{t}=$ the number of year and $\mathrm{N}=$ life span of the project. A given project is viable when its NPV is positive with the discount usually used rate by investors of the sector [14]. For two or more projects the most profitable project is the one with the highest NPV [14].

The Cash Flow is calculated from the following equation:

$$
\begin{gathered}
C F_{t}=R E V E N U E_{t}-O P E R A T I N G_{t}-D E B T_{t}-T A X_{t} \\
-R E S E R V E_{-} F U N D_{t}
\end{gathered}
$$

where:

$$
\begin{aligned}
& R E V E N U E_{t}=Q_{-} G A S_{t} * G A S_{-} P R I C E_{t} \\
& O P E R A T I N G_{t}=O P E R A T I N G_{1} *(1+I R)^{t-1} \\
& D E B T_{t}=\mathrm{LOAN} *(1+i R)^{P B T} / P B T \\
& T A X_{t}=\left(R E V E N U E_{t}-O P E R A T I N G_{t}-D E B T_{t}\right) * T R
\end{aligned}
$$$$
R E S E R V E_{-} F U N D_{t}=\left(R E V E N U E_{t}-O P E R A T I N G_{t}-\right.
$$$$
\left.D E B T_{t}-T A X_{t}\right) * R F R[1]
$$

Gas purchase costs are included in operating costs and Q_GAS is the quantity of gas bought in the year.

PI is defined has the ratio project NPV to the initial investment [27], i.e., PI $=\frac{N P V}{\text { Initial Investment }}$.

The higher the PI of the project the greater the profit from the implementation of that project [27].

\section{Assumptions}

1) General

720 tons (an average of $12 \mathrm{~kg}$ per household) of LPG to be delivered by each option; Inflation rate IR $=0.5 \%$ for gas price and $7 \%$ for other charges.

Annual tax on benefit rate TR $=30 \%$ used in Nigeria [1]; $\mathrm{N}=40$ years; The projects will be evaluated at three discount rates $10 \%, 15 \%$ and $20 \%$; Reserve Fund will be set for each option for repair of main infrastructures.

\section{2) Pipeline-Option Assumptions}

Federal Pipeline network of $150 \mathrm{~km}$ (40 in diameter, $12.7 \mathrm{~mm}$ thick) cuts across Rivers; State Pipeline network linking federal pipeline to Choba of $3 \mathrm{~km} \mathrm{(25} \mathrm{in} \mathrm{diameter,}$ $8 \mathrm{~mm}$ thick); State Pipeline distributing to 5000 homes in Choba though an approximate $20 \mathrm{~km}$ (10 in diameter, $4 \mathrm{~mm}$ thick) pipeline.

Initial investment is borrowed from bank at an annual composed interest rate $\mathrm{i}_{\mathrm{R}}=11 \%$ with constant annual payback over the payback time PBT $=12$ years; Annual Reserve Fund Rate (RFR) after taxes of 5\%; Refection/general maintenance each 5 years. Resources: 1 boosting station, 1 tank farm with two $350 \mathrm{~m}^{3}$-tanks and 1 pump and 1 pressure reduction station and 10-member staff for operation is used.

\section{3) Cylinder-Option Assumptions}

4 LPG filling plants of capacity of 10 metric tons to be built; 4 tanker truck of capacity of 10 metric tons to be acquired; Initial investment is borrowed from bank at an annual composed interest rate $i_{R}=9 \%$ with constant annual payback over the payback time PBT $=7$ years; Annual Reserve Fund Rate (RFR) after taxes of 5\%; Refection/general maintenance each 5 years. Resources: 2 LPG filling plants of 5 metrics tons each, 1 tanker truck of 10 metric ton and 7-member staff for operation is used.

\section{Results}

\section{1) Cylinder-Option}

Table I summarized the costs and prices used in the project economic evaluation and the results obtained.

\section{TABLE I: CYLINDER OPTION COSTS AND RESULT}

\begin{tabular}{cccc}
\hline $\begin{array}{c}\text { Costs/ } \\
\text { Prices }\end{array}$ & Capital Cost & $\begin{array}{c}\text { Gas purchase } \\
\text { price at year } \\
1 / \text { ton }\end{array}$ & $\begin{array}{c}\text { Gas sale } \\
\text { price at year } \\
1 / \text { ton }\end{array}$ \\
\hline Values $(\$)$ & 336,228 & 761 & 870 \\
NPV @ (\$) & $\mathrm{D}=10 \%$ & $\mathrm{D}=15 \%$ & $\mathrm{D}=20 \%$ \\
& $1,493,329$ & 475,351 & 211,786 \\
PI @ & $\mathrm{D}=10 \%$ & $\mathrm{D}=15 \%$ & $\mathrm{D}=20 \%$ \\
& 4.44 & 1.41 & 0.63 \\
\hline
\end{tabular}

\section{2) Pipeline-Option}

Table II summarized the costs and prices used in the project economic evaluation and the results obtained. Simulation is made for gas prices which lead to a nil NPV.

TABLE II: PIPELINE OPTION COSTS AND RESULTS

\begin{tabular}{cccc}
\hline Costs/ Prices & Capital Cost & $\begin{array}{c}\text { Gas purchase } \\
\text { price at year } \\
1 / \text { ton }\end{array}$ & $\begin{array}{c}\text { Gas sale price } \\
\text { at year 1/ton }\end{array}$ \\
\hline Values $(\$)$ & 12746500 & 761 & 870 \\
NPV @ (\$) & $\mathrm{D}=10 \%$ & $\mathrm{D}=15 \%$ & $\mathrm{D}=20 \%$ \\
& $-21,477,383$ & $-16,996,402$ & $-13,615,753$ \\
PI @ & $\mathrm{D}=10 \%$ & $\mathrm{D}=15 \%$ & $\mathrm{D}=20 \%$ \\
Gas prices for & $-1,68$ & $-1,33$ & $-1,07$ \\
NPV =0 & $\mathrm{D}=10 \%$ & $\mathrm{D}=15 \%$ & $\mathrm{D}=20 \%$ \\
Gas sale & $3,244.925$ & $4,037.355$ & $4,633.075$ \\
price/870 & 3.73 & 4.64 & 5.33 \\
\hline
\end{tabular}




\section{3) Interpretation of Results}

Under the assumptions made above, the Cylinder-Option is viable with NPV of $1,493,329 ; 475,351 ; 211,786$ and profitability index PI of 4.44, 1.41 and 0.63 for a discounted rate of respectively $10 \%, 15 \%$ and $20 \%$, respectively.

As far as Pipeline-Option is concerned, the NPV of the project are negative with the same initial gas sale price of $\$ 870$ for the three discount rate. At discount rate $10 \%, 15 \%$ and $20 \%$, the gas must be initially sold at $\$ 3,244.925$; $\$ 4,037.355$ and $\$ 4,633.075$ per ton respectively before getting the initial investment paid back. What makes respectively $3.73,4.64$, and 5.33 times the initial gas sale price of $\$ 870$. Thus, the government is in the best position to invest in this option since there is a high need to utilize the gas produced in Nigeria in-country through effective distribution. Also, due to the much environmental benefit, job creation, improved service delivery and the social aspect of vital service provision to citizens. This option could also improve the tunnel system of distribution of services in Nigeria.

\section{Impacts of Distribution Network on the Economy \\ 1) Cost}

The government will be able to cut the cost of distribution to home and storage of its large reserves to a considerable percentage in few years' time.

\section{2) Control}

With full gas pipeline network distribution grids to homes, the government can be able to efficiently control the pricing, delivery, monitoring and safety of LPG within the country.

\section{3) Utilization}

The large reserves of gas will eventually meet the domestic and commercial needs of the citizens and simultaneously increasing utilization at a low cost.

\section{B. Environmental Analysis}

The portion of the pipeline from the gas processing plant (Greenville Rumuji) - about $15 \mathrm{~km}$ - located within the residential area is the highest hazard from the survey. Also, the highest environmental impacts are on physical and human activities.

TABLE III: ENVIRONMENTAL IMPACTS IDENTIFICATION

\begin{tabular}{|c|c|c|c|c|c|c|c|c|c|c|}
\hline \multirow[b]{2}{*}{$\begin{array}{l}\text { Environmental Impact } \\
\text { Identification }\end{array}$} & \multicolumn{4}{|c|}{ Physical } & \multicolumn{2}{|c|}{ Bio } & \multicolumn{4}{|c|}{ Human } \\
\hline & 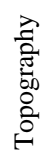 & 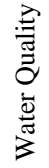 & 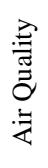 & 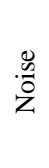 & 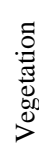 & 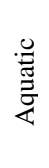 & 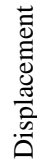 & 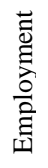 & 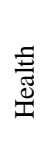 & $\stackrel{\stackrel{\Xi}{\Xi}}{\stackrel{\Xi}{\Xi}}$ \\
\hline $\begin{array}{l}\text { Land / Site } \\
\text { development }\end{array}$ & X & & & $X$ & $\mathrm{X}$ & & $X$ & $X$ & & $\mathrm{X}$ \\
\hline $\begin{array}{l}\text { Water requirement / } \\
\text { use }\end{array}$ & & $\mathrm{X}$ & $\mathrm{X}$ & & & $\mathrm{X}$ & & $X$ & & \\
\hline $\begin{array}{l}\text { Piping / structural } \\
\text { work }\end{array}$ & $X$ & $X$ & $X$ & $X$ & $\mathrm{X}$ & & $X$ & $X$ & & \\
\hline $\begin{array}{l}\text { Mechanical / Electrical } \\
\text { work }\end{array}$ & & & & $X$ & & & $X$ & X & & \\
\hline LPG Storage & & & $X$ & & & & $X$ & $X$ & $X$ & \\
\hline Civil works & $\mathrm{X}$ & & $X$ & $\mathrm{X}$ & & & & $\mathrm{X}$ & & \\
\hline $\begin{array}{l}\text { Transport and } \\
\text { Logistics }\end{array}$ & $\mathrm{X}$ & & $X$ & $X$ & & & & $\mathrm{X}$ & $X$ & $\mathrm{X}$ \\
\hline Employment & & & & & & & & $X$ & & $X$ \\
\hline
\end{tabular}

The study showed high impact for fire and explosion hazards, however, with little frequency of occurrence. The most dangerous points along the pipeline sections are the gas station and the market junction with high fire risks.

The assessment showed that major causes may be pipe defects, third party damage such as vandalism and community action, corrosion, construction errors, environmental factors, pipeline leakage.

TABLE IV: ENVIRONMENTAL IMPACT ASSESSMENT (EIA)

\begin{tabular}{|c|c|c|c|c|c|}
\hline \multirow[t]{2}{*}{ Environmental Impacts } & \multicolumn{2}{|c|}{ Category } & \multicolumn{3}{|c|}{ Impact } \\
\hline & Risk & Benefit & Low & Mid & High \\
\hline Land depreciation & $\mathrm{X}$ & & $\mathrm{X}$ & & \\
\hline Loss of and displacement & $X$ & & $X$ & & \\
\hline $\begin{array}{l}\text { Depreciation of } \\
\text { environmental aesthetics }\end{array}$ & $\mathrm{X}$ & & $\mathrm{X}$ & & \\
\hline Erosion/ Silt runoff & $\mathrm{X}$ & & $\mathrm{X}$ & & \\
\hline Water quality & $\mathrm{X}$ & & $X$ & & \\
\hline $\begin{array}{l}\text { Air Pollution from LPG } \\
\text { discharge }\end{array}$ & $\mathrm{X}$ & & & $\mathrm{X}$ & \\
\hline Explosion / Fire & & & & & $\mathrm{X}$ \\
\hline Pollution from solid waste & & & $\mathrm{X}$ & & \\
\hline Occupational health hazard & $\mathrm{X}$ & & & $X$ & \\
\hline Odor hazard & $\mathrm{X}$ & & $\mathrm{X}$ & & \\
\hline Noise hazard & & & $X$ & & \\
\hline Employment / Culture & & $\mathrm{X}$ & & & $\mathrm{X}$ \\
\hline $\begin{array}{l}\text { Disruption to drainage } \\
\text { pattern }\end{array}$ & & & $\mathrm{X}$ & & \\
\hline $\begin{array}{l}\text { Encroachment into } \\
\text { precious ecology }\end{array}$ & $\mathrm{X}$ & & $X$ & & \\
\hline Worker accident & $\mathrm{X}$ & & & $\mathrm{X}$ & \\
\hline
\end{tabular}

From the Hazard Identification performed, below are the major hazards, with the recommended mitigations:

\section{1) Human Errors}

Regular employee safety training and promotion of public safety awareness.

2) Construction errors, design flaws, pipe defects, welding and construction defects, pipe, equipment, device, too accessory defects, and corrosion failure

Use of competent design and construction personnel, and adhering to a high standard of quality control

3) Environmental and natural disasters such as floods and earthquakes

Adequate supervision and protection of the pipeline, contingency plan should be in place to reduce accident loss and control damages in case of emergency, routine inspections of the pipeline network to reduce accident rate.

\section{4) Explosion}

Promotion of public safety awareness and adequate pipeline network security. Also, pipeline compartmentalization around the high risk areas may minimize the risk of fire and explosions.

\section{Conclusions}

Purchasing cooking gas during the COVID-19 pandemic was quite difficult in Nigeria due to the lockdown and lack of direct distribution to homes. This poised the initiation of the proposed LPG distribution plan for Rivers State. This research has carefully analyzed LPG distribution to homes in Choba as a strategic case study. Choba was mapped out and control units were positioned with an operational plan inputted in the economic analysis for the seamless running of 
the proposed distribution plan.

With a very large proven gas reserve in Nigeria, the country is eager to utilize the benefits of its resources to its fullest. The research has shown that is feasible for the government to invest in the pipeline option, and the qualitative \& quantitative analysis has also shown that benefits will be increased based on services, employment creation, technology, new streams of gas usage and national security.

Results from this study further takes into consideration basic factors to minimize the negative impacts of LPG distribution on environment through a thorough environmental impact assessment (EIA) conducted for the purpose of sustainable development.

\section{RECOMMENDATIONS}

The cost of development of pipeline routes for such a huge project could be challenging for already developed areas. Also, the combination of environmental and demographicspecific factors for identification of its potential environmental impacts are very important. However newly developed settlements or future settlements (e.g., Greater Portharcourt City) and appropriate mitigation measures can make such provision available to increase gas utilization in Nigeria.

More uses for Natural gas within Nigeria are encouraged, as this will boost the efficiency of the pipeline distribution network. Also, further strategies for tunneling and laying of pipelines in a safer and more environmentally friendly manner could be further research on to support the feasibility of this research propositions.

According to Penresa in 2017, crude oil has been a major choice for fuel within Nigeria, however the course is changing under the President Buhari's Gas revolution [18]. This implies that the environment is rosy for gas exploration, production, distribution, and utilization in Nigeria, therefore, more research to consolidate this venture should be encouraged. The Petroleum Industry Bill (PIB) is not left behind in this effect, therefore, more laws to protect the investment of gas utilization is also recommended.

\section{CONFLICT OF INTEREST}

No conflict of Interest.

\section{ACKNOWLEDGMENT}

We acknowledge God almighty of the divine insight to carry out a successful research. The Institute of Petroleum Studies, University of Portharcourt also played a role in equipping us with a background knowledge for researches around petroleum studies.

\section{REFERENCES}

[1] Adamu A. and a Darma R. (2017). Economic Analysis of Gas Pipeline Projects in Nigeria. Journal of Economics and Sustainable Development, 8(2), ISSN 2222-1700.

[2] Bamidele O. (2019). Shell Expands Domestic Gas Distribution in Nigeria, SPDC Press release. https://www.shell.com.ng/media/2019- media-releases/shell-expands-domestic-gas-distribution-innigeria.html.

[3] Buhari, Osinbajo flag-off Ajokuta-Kaduna-Kano Gas Pipeline Project (2020, June 30). Vanguard Newspaper: News, https://www.vanguardngr.com/2020/06/buhari-osinbajo-flag-offajaokuta-kaduna-kano-gas-pipeline-project/.

[4] Chikwe T. N., Osuji L. C. and Okoye I. P. (2016). Adulteration of PMS [Gasoline] with Condensates: Impact on Quality Assurance Parameters, J. Chem. Soc. Nigeria, 41(2), 113-117.

[5] EIA (2019). Natural Gas Pipelines, US Energy Information Administration, Washington, DC 20585 https://www.eia.gov/energyexplained/natural-gas/natural-gaspipelines.php.

[6] Faruq U. Z., Runde M., Danshehu B. G., Yahaya H. N., Zuru A. A. and Muhammad A. B. (2012). Comparative Studies of Gasoline Samples Used in Nigeria, Nigerian Journal of Basic and Applied Science 20(2), 87-92, ISSN 0794-5698.

[7] Global Energy Monitor Wiki (2021, March 16). Oil and Gas Pipeline Construction Costs, Global Energy Monitor Wiki. www.gem.wiki/Oil_and_Gas_Pipeline_Construction_Costs.

[8] Greenville LNG (2018). Press/News Articles https://www.greenvillelng.com/press-article.html.

[9] Greenville LNG (2020). Rumuji Plant, Project Greenville. https://www.greenvillelng.com/rumuji-plant.

[10] Igwe G. J. I., Wami E. N. and Ewili J. M. (1988). Problems and Prospects of Natural Gas Transmission and Distribution in Nigeria, Society of Petroleum Engineers, 278-293. DOI: https://doi.org/10.2118/17732-MS.

[11] Kenanah S. (2016). Economics Modeling for Petroleum Exploration and Production Projects Considering Risk and imprecise Data. der Technischen Universität Berlin. 23-26.

[12] Lim, S.S., et al., (2012). A comparative risk assessment of burden of disease and injury attributable to 67 risk factors and risk factor clusters in 21 regions, 1990 - 2010: asystematic analysis for the Global Burden of Disease Study 2010. https://doi.org/10.1016/S0140-6736(12)617668 .

[13] Marc W. M., Ogla S. and Michael P. (2013). Blending Hydrogen into Natural Gas Pipeline Networks: A Review of Key Issues, National Renewable Energy Laboratory, Denver West Parkway Golden, Colorado.

[14] McGrayA. W. (1975). Petroleum evaluation and economic decision. School of Petroleum and Geological Engineering, University of Oklahoma.

[15] NAPIMS, Obiafu Plant https://www.napims.com/obiafu.html.

[16] Nicholas N. (2018). Emerging economies to fuel smart gas metering systems market expansion, Smart Energy International, South Africa

[17] OPEC (2019). About Nigeria, OPEC Annual Statistical Bulletin. https://www.opec.org/opec_web/en/about_us/167.htm.

[18] Penresa (2017, December 22). "Nigeria's Gas revolution" https://www.penresa.com/nigerias-gas-revolution/.

[19] Scondo A. (2019). PPD 811-2: Production Operations, IFP Training, [PowerPoint Slides]

[20] SNG (2017) Distribution Network, https://www.shell.com.ng/aboutus/what-we-do/sng/distribution-network.html.

[21] Sohrab Zendehboudi and Alireza Bahadori (2016). Mercaptans, Shale Oil and Gas Handbook, $1^{\text {st }}$ Edition, ISBN: 9780128021132.

[22] Tayo O. (2019, September 25) Demand for gas cylinders rises as LPG conversion deepens, Guardian Newspaper: Energy https://m.guardian.ng/energy/demand-for-gas-cylinders-rises-as-lpgconversion-deepens/.

[23] Theodora. Nigeria Pipelines Map - Crude Oil (Petroleum) Pipelines Natural Gas Pipelines - Products Pipelineshttps://theodora.com/pipelines/nigeria_oil_gas_and_products _pipelines_map.html.

[24] UN, (2015). Transforming Our World. The 2030 Agenda for Sustainable Development. United Nations. http://bit.ly/2030agenda.

[25] WHO, (2016). Preventing Disease through Healthy Environments. A Global Assessment of the Burden of Disease from Environmental Risks. World Health Organization. https://cutt.ly/nkVeItC.

[26] Wizor H. C., and Elekwachi, W. (2019, August) Peri-Urban Housing and Environmental Quality Problems in Choba Town, Rivers State, Nigeria. IIARD International Journal of Geography and Environmental Management E-ISSN 2505-8821, Vol. 5 No. 2019.

[27] Yeghenee N. K and Oyinkepreye D. O. (2006). Economic Analysis of Innovative Approaches to Marginal Field Development. Society of Petroleum Engineers Inc. SPE 106001.

[28] Zakka A., Audrey J., Peter M. \& Mabel O (2020, July 2). Nigerian Gas Transportation Network Code - Highlights, Potential Challenges and Domestic Market Readiness [Webinar] Nigerian Gas Association www.nigeriangasassociation.org.ng/news.php. 